\title{
SIKAP ORANG TUA TERHADAP PEMBENTUKAN KEPRIBADIAN ANAK PADA KELUARGA PETANI DI DESA TALAWAAN BANTIK KECAMATAN WORI KABUPATEN MINAHASA UTARA
}

\author{
${ }^{1}$ Yunemey Teintang \\ ${ }^{2}$ Jehosua S.V. Sinolungan \\ ${ }^{2}$ Henry Opod
}

\author{
${ }^{1}$ Kandidat Skripsi Fakultas Kedokteran Universitas Sam Ratulangi Manado \\ ${ }^{2}$ Bagian Psikologi Fakultas Kedokteran Universitas Sam Ratulangi Manado \\ Email: yunemey_teintang@rocketmail.com
}

\begin{abstract}
Most farmers are not high educated, however, they can get a lot of information about attitude from other people and media. This study aimed to obtain parents' attitudes toward the formation of children personality in Talawaan Bantik, Wori, North Minahasa. Ths was a quantitative descriptive study. Data were colleced by using interview and observation, meanwhile data collecting tools were guided by using interviews, questionnaires, and documentation study. The results showed that the attitude of parents influenced the formation of the child's personality. Parents who cared their children with loving personality produced more responsible children, friendly children, and creative children. The attitude of parents who spoiled their children could produce lazy personality. The attitude of parents who gave physically punishment to the children could produced children with moody and timid personality. The attitude of parents who taught children to socialize with their surroundings coould resulted in children who were good in speaking.
\end{abstract}

Keywords: attitudes of parents, farmer family, child's personality

\begin{abstract}
Abstrak: Pekerjaan sebagai petani ditekuni orang tua yang mayoritas tidak berpendidikan tinggi namun sudah mendapat banyak informasi mengenai sikap melalui orang lain dan media. Penelitian ini bertujuan untuk mendapatkan gambaran sikap orang tua terhadap pembentukan kepribadian anak di Desa Talawaan Bantik Kecamatan Wori Kabupaten Minahasa Utara. Penelitian ini menggunakan metode deskriptif kuantitatif. Teknik pengumpulan data yaitu melalui wawancara, observasi, dan dokumentasi sedangkan alat pengumpulan data yaitu panduan wawancara, kuisioner, serta studi dokumentasi. Analisis data secara kualitatif. Hasil penelitian mmperlihatkan sikap orang tua berpengaruh terhadap terbentuknya kepribadian anak. Orang tua yang bersikap mendidik anak dengan penuh kasih sayang menghasilkan kepribadian anak yang lebih bertanggung jawab, anak yang ramah, anak yang kreatif. Sikap orang tua yang terlalu memanjakan anak dapat menghasilkan kepribadian anak yang pemalas. Sikap orang tua yang memberikan hukuman fisik kepada anak dapat menghasilkan kepribadian anak yang pemurung, anak yang penakut. Sikap orang tua yang mengajarkan anak bersosialisasi dengan lingkungan sekitar dapat menghasilkan kepribadian anak yang mempunyai ketrampilan berbahasa yang baik.
\end{abstract}

Kata kunci: sikap orang tua, keluarga petani, kepribadian anak

Perkembangan suatu bangsa sangat ditentukan oleh keluarga. Orang tua memegang peranan penting dalam membentuk kepribadian anak. ${ }^{1}$ Setiap bangsa punya cara unik dan khas dalam hal bersikap kepada anak. Sebab hal ini erat kaitannya dengan budaya setempat. ${ }^{2}$ Sementara itu orang tua di Sulawesi Utara 
khususnya Minahasa bersikap progresif atau ada istilah "dengan cara Belanda" yaitu sikap dengan kadar disiplin yang tinggi, ada juga yang bersikap selalu mengiyakan keinginan anak. ${ }^{3}$ Berdasarkan data dari Komisi Nasional Anak Indonesia terdapat 139 kasus tawuran pelajar selang enam bulan pertama di tahun 2010. Hal ini lebih banyak dibandingkan dengan tahun 2009 yang jumlahnya 128 kasus. Berdasarkan data dari Komisi Nasional Anak Indonesia, kasus kenakalan anak di Sulawesi Utara pada tahun 2010 berjumlah 67 kasus; 42 kasus di antaranya ialah perkelahian anak, sedangkan sisanya ialah kasus pencurian. Dari kasus perkelahian anak, 3 di antaranya mengakibatkan kematian. ${ }^{4}$ Berdasarkan survei awal peneliti mendapatkan informasi bahwa di desa Talawaan Bantik kecamatan Wori kabupaten Minahasa Utara sering dijumpai anak-anak yang suka berkelahi, mencuri, berbohong kepada orang tua, dan bermalasmalasan. Tujuan penelitian ini ialah untuk mengetahui sejauh mana pemahaman orang tua tentang sikap dan kepribadian anak, pengaruh sikap orang tua terhadap kepribadian anak, dan berbagai kepribadian anak berdasarkan sikap orang tua.

Sikap adalah kesiapan dari diri untuk bertindak atau bereaksi dengan cara tertentu. Sikap sering muncul dari berbagai penilaian. Terdapat 3 model sikap yang dikembangkan, ${ }^{5-7}$ sebagai berikut: 1) Respon afektif, yaitu respon fisiologis yang mengekspresikan kesukaan individu pada sesuatu; 2) Kecenderungan perilaku, yaitu indikasi verbal dari maksud seorang individu; dan 3) Respon kognitif, yaitu pengevaluasian secara kognitif terhadap suatu obyek.

Terdapat berbagai macam sikap orang tua terhadap anak, seperti:

1. mengekang dan tidak membiarkan anak memiliki ruang gerak sendiri, tidak mengizinkan anak memiliki pendapat sendiri, minat berbeda atau melakukan sesuatu yang berbeda. Akibatnya anak tumbuh menjadi orang yang bergantung pada orang lain. Menjadi keras kepala dan sulit diatur. Gaya mendidik seperti ini diperlukan lebih banyak pada usia dini dan hendaknya semakin demokratis ketika remaja dan semakin dewasa. ${ }^{8}$

2. Sikap orang tua yang ditandai dengan adanya kebebasan tanpa batas kepada anak untuk berperilaku sesuai dengan keinginan anak. Akibatnya anak menjadi tampak kurang matang atau manja walaupun tampak responsif dalam belajar, mementingkan diri sendiri, kurang percaya diri, mudah menyerah dalam menghadapi masalah dan kesulitan bahkan tidak jarang perilaku menjadi agresif.

3. Sikap yang terbuka antara orang tua dan anak. Orang tua membuat aturan yang disepakati bersama. Akibatnya anak menjadi mandiri, tegas terhadap diri sendiri dan memiliki kemampuan introspeksi serta pengendalian diri, mudah bekerjasama dengan orang lain dan kooperatif terhadap aturan, lebih percaya diri akan kemampuannya menyelesaikan tugas-tugas, memiliki ketrampilan sosial yang baik dan terampil menyelesaikan permasalahan, kreatif, bermotivasi dan berprestasi. ${ }^{8}$

Kata kepribadian berakar dari kata dasar pribadi, yang menunjuk diri seseorang dengan segala seluk-beluknya secara perorangan/ seseorang. Istilah asingnya dari kata Yunani = prosopon; Belanda = person; Inggris = personality; dan Latin $=$ persona.${ }^{5}$ Kepribadian bukan sebagai bakat kodrati, melainkan terbentuk oleh proses sosialisasi. Kepribadian merupakan kecenderungan psikologis seseorang untuk melakukan tingkah laku sosial tertentu baik bersikap dan berkehendak maupun perbuatan. ${ }^{9}$

Terdapat 2 faktor yang memengaruhi kepribadian, yaitu :1) Faktor Internal; yang berasal dalam diri anak itu sendiri seperti faktor yang berhubungan dengan konsitusi tubuh, struktur tubuh dan keadaan fisik, koordinasi motorik, kemampuan mental dan bakat khusus. 2) Faktor eksternal; yaitu keluarga dan lingkungan. ${ }^{10}$

Kriteria kepribadian menurut Kilander, yaitu: ${ }^{11}$ 
1. Mampu menyayangi orang lain dan mempertimbangkan minat orang lain dalam tindakan-tindakannya.

2. Memiliki hubungan sosial yang kualitasnya memuaskan dan berlangsung lama.

3. Bersikap baik terhadap orang lain dan mempercayainya dengan hadapan bahwa ia pun diharapkan orang lain untuk mempercayai dan menyukainya.

4. Menghargai perbedaan-perbedaan yang terdapat pada banyak orang.

5. Tidak memaksa lingkungan, tetapi juga tidak membiarkan diri mereka dipaksa atau ditekan oleh lingkungan.

6. Dapat merasakan bahwa mereka adalah bagian dari kelompok atau populasinya.

7. Merasakan adanya sense of responsibility atas orang lain. ${ }^{11}$

Sikap orang tua terhadap anak sangat mempengaruhi kepribadian anak, ${ }^{1}$ yaitu :

1. Pemahaman budi pekerti sejak dini.

2. Mendisiplinkan anak.

3. Menyayangi anak secara wajar.

4. Menghindari pemberian label "malas" pada anak.

5. Hati-hati dalam menghukum anak.

Kekerasan kepada anak menimbulkan rasa sakit secara fisik serta psikis, sehingga lambat laun rasa percaya diri dan harga dirinya akan terpuruk. ${ }^{12,13}$

\section{METODE PENELITIAN}

Penelitian dilaksanakan untuk mendapatkan gambaran keadaan yang sedang berlangsung di lapangan pada waktu pelaksanaan penelitian. ${ }^{14}$ Metode yang digunakan ialah deskriptif kuantitatif. Sampel ialah bagian dari populasi yang akan diteliti. ${ }^{15,16}$

Penelitian dilaksanakan pada Desa Talawaan Bantik Kecamatan Wori Kabupaten Minahasa Utara dengan populasi yaitu seluruh kepala keluarga yang berprofesi sebagai petani sejumlah 130 responden dengan sampel yang mempunyai anak usia sampai dengan 18 tahun. Pada bulan Februari sampai dengan April 2011. Teknik yang digunakan ialah simple random sampling. ${ }^{17}$ Data diperoleh melalui wawancara, kuisioner. dan dokumentasi.

\section{HASIL PENELITIAN}

Dari Tabel 1 dapat dilihat bahwa responden terbanyak yaitu pada umur 3140 tahun berjumlah 60 responden (46\%), sedangkan yang paling sedikit ialah umur $\leq$ 30 tahun 7 responden (5\%).

Tabel 1. Distribusi responden berdasarkan umur

\begin{tabular}{ccc}
\hline $\begin{array}{c}\text { Umur } \\
\text { (tahun) }\end{array}$ & $\mathrm{N}$ & $\%$ \\
\hline$\leq 30$ & 41 & 32 \\
$31-40$ & 60 & 46 \\
$41-50$ & 22 & 17 \\
$\geq 50$ & 7 & 5 \\
Jumlah & 130 & 100 \\
\hline
\end{tabular}

Dari Tabel 2 dapat dilihat bahwa sebagian besar responden ialah laki-laki (83\%).

Tabel 2. Distribusi responden berdasarkan jenis kelamin

\begin{tabular}{ccc}
\hline Jenis kelamin & $\mathrm{N}$ & $\%$ \\
\hline Laki-laki & 108 & 83 \\
Perempuan & 22 & 17 \\
Jumlah & 130 & 100 \\
\hline
\end{tabular}

Dari Tabel 3 dapat dilihat bahwa tingkat pendidikan responden terbanyak SMP/sederajat (43\%) sedangkan paling sedikit ialah SD/sederajat dan Diploma/ sarjana (3\%).

Tabel 3. Distribusi responden berdasarkan pendidikan

\begin{tabular}{ccc}
\hline Pendidikan & N & $\%$ \\
\hline SD / sederajat & 39 & 30 \\
SMP / sederajat & 56 & 43 \\
SMA / sederajat & 31 & 24 \\
Perguruan Tinggi & 4 & 3 \\
Jumlah & 130 & 100 \\
\hline
\end{tabular}

Dari Tabel 4 dapat dilihat bahwa 88\% responden setuju bahwa orang tua harus bersikap sopan kepada anak dalam memberi perintah sedangkan 5\% responden 
Teintang, Sinolungan, Opod: Sikap orang tua terhadap pembentukan kepribadian anak ...

menyatakan kadang-kadang orang tua harus bersikap sopan kepada anak dalam memberi perintah.

Tabel 4. Distribusi responden berdasarkan pengetahuan atau informasi dari orang lain atau media tentang sikap

\begin{tabular}{ccc}
\hline Keterangan & N & $\%$ \\
\hline Tidak pernah & 0 & 0 \\
Hampir tidak pernah & 0 & 0 \\
Kadang-kadang & 6 & 5 \\
Sering & 115 & 88 \\
Setuju & 9 & 7 \\
Jumlah & 130 & 100 \\
\hline
\end{tabular}

Dari Tabel 5 dapat di lihat bahwa 95\% responden setuju bahwa orang tua mewajibkan anak memberi hormat ketika pergi dan pulang sekolah. Terdapat 5\% berpendapat bahwa sering orang tua mewajibkan anak memberi hormat ketika pergi dan pulang sekolah.

Tabel 5. Distribusi responden berdasarkan budi pekerti kepada anak dalam hal orang tua mewajibkan anak memberi hormat ketika pergi dan pulang sekolah

\begin{tabular}{ccc}
\hline Keterangan & $\mathrm{N}$ & $\%$ \\
\hline Tidak pernah & 0 & 0 \\
Hampir tidak pernah & 0 & 0 \\
Kadang-kadang & 0 & 0 \\
Sering & 6 & 5 \\
Setuju & 124 & 95 \\
Jumlah & 130 & 100 \\
\hline
\end{tabular}

Dari Tabel 6 dapat dilihat bahwa 98\% responden sering memberikan kasih sayang kepada anak, sedangkan 2\% responden setuju memberikan kasih sayang terhadap anak.

Tabel 6. Distribusi responden berdasarkan pemberian kasih sayang terhadap anak

\begin{tabular}{ccc}
\hline Kerterangan & $\mathrm{N}$ & $\%$ \\
\hline Tidak pernah & 0 & 0 \\
Hampir tidak pernah & 0 & 0 \\
Kadang-kadang & 0 & 0 \\
Sering & 127 & 98 \\
Setuju & 3 & 2 \\
Jumlah & 130 & 100 \\
\hline
\end{tabular}

Dari Tabel 7 dapat dilihat bahwa 85\% responden menyatakan kadang-kadang memberikan hadiah kepada anak, sedangkan 7\% tidak pernah memberikan hadiah kepada anak.

Tabel 7. Distribusi responden berdasarkan pemberian kasih sayang kepada anak dalam hal orang tua memberikan hadiah kepada anak

\begin{tabular}{ccc}
\hline Keterangan & $\mathrm{N}$ & $\%$ \\
\hline Tidak pernah & 0 & 0 \\
Hampir tidak pernah & 0 & 0 \\
Kadang-kadang & 111 & 85 \\
Sering & 10 & 8 \\
Setuju & 9 & 7 \\
Jumlah & 130 & 100 \\
\hline
\end{tabular}

Dari Tabel 8 dapat dilihat bahwa 83\% responden kadang-kadang memanjakan dan mengabulkan setiap keinginan anak, sedangkan $8 \%$ responden setuju mengabulkan setiap keinginan anak.

Tabel 8. Distribusi responden berdasarkan sikap memanjakan anak dalam hal mengabulkan setiap keinginan anak

\begin{tabular}{ccc}
\hline Keterangan & $\mathrm{N}$ & $\%$ \\
\hline Tidak pernah & 0 & 0 \\
Hampir tidak & 0 & 0 \\
pernah & & \\
Kadang-kadang & 108 & 83 \\
Sering & 12 & 9 \\
Setuju & 10 & 8 \\
Jumlah & 130 & 100 \\
\hline
\end{tabular}

Dari tabel 9 dapat dilihat bahwa 76\% responden kadang-kadang memberikan hukuman fisik kepada anak, sedangkan 5 \% responden hampir tidak pernah memberikan hukuman fisik kepada anak dan $5 \%$ sering memberikan hukuman fisik kepada anak.

Dari Tabel 10 dapat dilihat bahwa 89\% responden setuju bahwa menyekolahkan anak pada sekolah terkenal agar bisa pintar, sedangkan $1 \%$ tidak pernah.

Dari Tabel 11 dapat dilihat bahwa 81\% responden, memiliki anak yang tidak pernah menyelesaikan sendiri masalahnya. 
Tabel 9. Distribusi responden berdasarkan sikap disiplin terhadap anak

\begin{tabular}{ccc}
\hline Keterangan & $\mathrm{N}$ & $\%$ \\
\hline Tidak pernah & 7 & 5 \\
Hampir tidak pernah & 18 & 14 \\
Kadang-kadang & 99 & 76 \\
Sering & 6 & 5 \\
Setuju & 0 & 0 \\
Jumlah & 130 & 100 \\
\hline
\end{tabular}

Tabel 10. Distribusi responden berdasarkan pendidikan anak

\begin{tabular}{ccc}
\hline Keterangan & $\mathrm{N}$ & $\%$ \\
\hline Tidak pernah & 1 & 1 \\
Hampir tidak & 0 & 0 \\
pernah & & \\
Kadang-kadang & 8 & 6 \\
Sering & 5 & 4 \\
Setuju & 116 & 89 \\
Jumlah & 130 & 100 \\
\hline
\end{tabular}

Tabel 11. Distribusi responden berdasarkan masalah dan keluhan anak

\begin{tabular}{ccc}
\hline Keterangan & $\mathrm{N}$ & $\%$ \\
\hline Tidak pernah & 105 & 81 \\
Hampir tidak pernah & 14 & 11 \\
Kadang-kadang & 10 & 8 \\
Sering & 1 & 0 \\
Setuju & 0 & 0 \\
Jumlah & 130 & 100 \\
\hline
\end{tabular}

Dari Tabel 12 dapat dilihat bahwa 94\% responden setuju anak selalu melakukan pekerjaan di rumah, 3\% sering melakukan pekerjaan di rumah, sedangkan 3\% kadangkadang melakukan pekerjaan di rumah.

Tabel 12. Distribusi responden berdasarkan tugas anak dirumah

\begin{tabular}{ccc}
\hline Keterangan & $\mathrm{N}$ & $\%$ \\
\hline Tidak pernah & 0 & 0 \\
Hampir tidak & 0 & 0 \\
pernah & & \\
Kadang-kadang & 4 & 3 \\
Sering & 4 & 3 \\
Setuju & 122 & 94 \\
Jumlah & 130 & 100 \\
\hline
\end{tabular}

Dari Tabel 13 dapat di lihat bahwa (81\%) responden menyatakan kadangkadang bersikap tidak jujur terhadap anak. $10 \%$ responden hampir tidak pernah bersikap jujur terhadap anak dan 7\% tidak pernah bersikap jujur terhadap anak.

Tabel 13. Distribusi responden berdasarkan sikap kejujuran orang tua

\begin{tabular}{ccc}
\hline Keterangan & $\mathrm{N}$ & $\%$ \\
\hline Tidak pernah & 9 & 7 \\
Hampir tidak & 13 & 10 \\
pernah & & \\
Kadang-kadang & 106 & 81 \\
Sering & 1 & 1 \\
Setuju & 1 & 1 \\
Jumlah & 130 & 100 \\
\hline
\end{tabular}

Dari Tabel 14 dapat dilihat bahwa 86\% responden setuju pernah mengajarkan anak bersosialisasi sedangkan 14\% responden sering mengajarkan anak bersosialisasi.

Tabel 14. Distribusi responden berdasarkan cara anak bersosialisasi di lingkungan sosial

\begin{tabular}{ccc}
\hline Keterangan & $\mathrm{N}$ & $\%$ \\
\hline Tidak pernah & 0 & 0 \\
Hampir tidak & 0 & 0 \\
pernah & & \\
Kadang-kadang & 0 & 0 \\
Sering & 18 & 14 \\
Setuju & 112 & 86 \\
Jumlah & 130 & 100 \\
\hline
\end{tabular}

Dari Tabel 15 dapat dilihat bahwa 82\% responden menyatakan bahwa anak kadang-kadang mempunyai sifat bertanggung jawab, sedangkan 2\% responden memiliki anak yang hampir tidak pernah memperlihatkan sifat bertanggung jawab.

Tabel 15. Distribusi responden berdasarkan kepribadian anak yang bertanggungjawab

\begin{tabular}{ccc}
\hline Keterangan & $\mathrm{N}$ & $\%$ \\
\hline Tidak pernah & 0 & 0 \\
Hampir tidak & 3 & 2 \\
pernah & & \\
Kadang-kadang & 107 & 82 \\
Sering & 11 & 9 \\
Setuju & 9 & 7 \\
Jumlah & 130 & 100 \\
\hline
\end{tabular}


Teintang, Sinolungan, Opod: Sikap orang tua terhadap pembentukan kepribadian anak ...

Dari Tabel 16 dapat dilihat bahwa 88\% responden memiliki anak yang sering memperlihatkan sikap ramah.

Tabel 16. Distribusi responden berdasarkan kepribadian anak yang ramah

\begin{tabular}{ccc}
\hline Keterangan & $\mathrm{N}$ & $\%$ \\
\hline Tidak pernah & 0 & 0 \\
Hampir tidak & 0 & 0 \\
pernah & & \\
Kadang-kadang & 0 & 0 \\
Sering & 16 & 12 \\
Setuju & 114 & 88 \\
Jumlah & 130 & 100 \\
\hline
\end{tabular}

Dari Tabel 17 dapat dilihat bahwa 78\% responden memiliki anak yang kadangkadang memiliki ide kreatif, 2\% responden memiliki anak yang hampir tidak pernah memiliki ide kreatif.

Tabel 17. Distribusi responden berdasarkan kepribadian anak yang kreatif

\begin{tabular}{ccc}
\hline Keterangan & $\mathrm{N}$ & $\%$ \\
\hline Tidak pernah & 0 & 0 \\
Hampir tidak & 2 & 2 \\
pernah & & \\
Kadang-kadang & 101 & 78 \\
Sering & 19 & 14 \\
Setuju & 8 & 6 \\
Jumlah & 130 & 100 \\
\hline
\end{tabular}

Dari Tabel 18 dapat di lihat bahwa 82\% responden memiliki anak yang kadang-kadang mempunyai kepribadian pemalas, $2 \%$ yang sering malas dan $1 \%$ memiliki anak yang malas.

Tabel 18. Distribusi responden berdasarkan kepribadian anak yang pemalas

\begin{tabular}{ccc}
\hline Keterangan & $\mathrm{N}$ & $\%$ \\
\hline Tidak pernah & 0 & 0 \\
Hampir tidak & 7 & 5 \\
pernah & & \\
Kadang-kadang & 106 & 82 \\
Sering & 16 & 12 \\
Setuju & 1 & 1 \\
Jumlah & 130 & 100 \\
\hline
\end{tabular}

Dari Tabel 19 dapat dilihat bahwa 68\% responden tidak pernah memiliki anak berkepribadian emosional, 9\% hampir tidak pernah emosional, 11\% kadang-kadang emosional, 4\% sering emosional, dan $8 \%$ memiliki anak emosional.

Tabel 19. Distribusi responden berdasarkan kepribadian anak yang emosional

\begin{tabular}{ccc}
\hline Keterangan & $\mathrm{N}$ & $\%$ \\
\hline Tidak pernah & 88 & 68 \\
Hampir tidak pernah & 12 & 9 \\
Kadang-kadang & 15 & 11 \\
Sering & 5 & 4 \\
Setuju & 10 & 8 \\
Jumlah & 130 & 100 \\
\hline
\end{tabular}

Dari Tabel 20 dapat dilihat bahwa 93\% responden tidak pernah memiliki anak berkepribadian pemurung, $1 \%$ memiliki anak yang kadang-kadang berkepribadian pemurung.

Tabel 20. Distribusi responden berdasarkan kepribadian anak yang pemurung

\begin{tabular}{ccc}
\hline Keterangan & $\mathrm{N}$ & $\%$ \\
\hline Tidak pernah & 121 & 93 \\
Hampir tidak pernah & 8 & 6 \\
Kadang-kadang & 1 & 1 \\
Sering & 0 & 0 \\
Setuju & 0 & 0 \\
Jumlah & 130 & 100 \\
\hline
\end{tabular}

Dari Tabel 21dapat dilihat bahwa 93\% responden kadang-kadang memiliki anak berkepribadian penakut, dan 17\% responden memiliki anak yang sering berkepribadian penakut.

Tabel 21. Distribusi responden berdasarkan kepribadian anak yang penakut

\begin{tabular}{ccc}
\hline Keterangan & $\mathrm{N}$ & $\%$ \\
\hline Tidak pernah & 0 & 0 \\
Hampir tidak pernah & 0 & 0 \\
Kadang-kadang & 108 & 83 \\
Sering & 22 & 17 \\
Setuju & 0 & 0 \\
Jumlah & 130 & 100 \\
\hline
\end{tabular}


Dari Tabel 22 dapat dilihat bahwa 83\% responden memiliki anak yang kadangkadang mempunyai ketrampilan berbahasa yang baik, $8 \%$ sering memiliki anak yang mempunyai ketrampilan berbahasa yang baik, dan 9\% memiliki anak yang mempunyai ketrampilan bahasa yang baik.

Tabel 22. Distribusi responden berdasarkan kepribadian anak yang pintar berbicara

\begin{tabular}{ccc}
\hline Keterangan & $\mathrm{N}$ & $\%$ \\
\hline Tidak pernah & 0 & 0 \\
Hampir tidak & 0 & 0 \\
pernah & & \\
Kadang-kadang & 109 & 83 \\
Sering & 10 & 8 \\
Setuju & 11 & 9 \\
Jumlah & 130 & 100 \\
\hline
\end{tabular}

Dari Tabel 23 dapat dilihat bahwa 90\% responden kadang-kadang memiliki anak berkepribadian pemalu, $2 \%$ responden memiliki anak yang sering berkepribadian pemalu, dan $8 \%$ responden memiliki anak yang berkepribadian hampir tidak pernah pemalu.

Tabel 23. Distribusi responden berdasarkan kepribadian anak yang pemalu

\begin{tabular}{ccc}
\hline Keterangan & $\mathrm{N}$ & $\%$ \\
\hline Tidak pernah & 0 & 0 \\
Hampir tidak pernah & 10 & 8 \\
Kadang-kadang & 117 & 90 \\
Sering & 3 & 2 \\
Setuju & 0 & 0 \\
Jumlah & 130 & 100 \\
\hline
\end{tabular}

Dari Tabel 24 dapat dilihat bahwa 92\% responden tidak pernah memiliki anak yang berkepribadian sulit bergaul dengan orang lain, 5\% responden memiliki anak yang hampir tidak pernah sulit bergaul dengan orang lain, dan 3\% memiliki anak yang kadang-kadang sulit bergaul dengan orang lain.

Dari Tabel 25 dapat di lihat bahwa 89\% responden memiliki anak yang kadang-kadang mempunyai kepribadian percaya diri, 7\% responden memiliki anak yang kadang-kadang mempunyai kepriba- dian percaya diri, dan $4 \%$ responden memiliki anak yang mempunyai kepribadian percaya diri.

Tabel 24. Distribusi responden berdasarkan kepribadian anak yang sulit bergaul dengan orang lain

\begin{tabular}{ccc}
\hline Keterangan & $\mathrm{N}$ & $\%$ \\
\hline Tidak pernah & 120 & 92 \\
Hampir tidak pernah & 6 & 5 \\
Kadang-kadang & 4 & 3 \\
Sering & 0 & 0 \\
Setuju & 0 & 0 \\
Jumlah & 130 & 100 \\
\hline
\end{tabular}

Tabel 25. Distribusi responden berdasarkan kepribadian anak yang percaya diri

\begin{tabular}{ccc}
\hline Keterangan & $\mathrm{N}$ & $\%$ \\
\hline Tidak pernah & 0 & 0 \\
Hampir tidak pernah & 0 & 0 \\
Kadang-kadang & 116 & 89 \\
Sering & 9 & 7 \\
Setuju & 5 & 4 \\
Jumlah & 130 & 100 \\
\hline
\end{tabular}

\section{BAHASAN}

Responden terbanyak berusia 31-40 tahun yaitu $46 \%$ dengan $83 \%$ berjenis kelamin laki-laki dan $43 \%$ tingkat pendidikan SMP. Sikap orang tua sangat memengaruhi kepribadian anak. Orang tua bertanggung jawab dalam penanaman sikap sopan santun dan budi pekerti. Hasil penelitian sebanyak $88 \%$ responden menyatakan sering bersikap sopan kepada anak dalam hal memberi perintah, 95\% responden setuju anak harus memberi hormat kepada orang tua ketika pergi dan pulang sekolah.

Sikap orang tua yang menyayangi anak secara wajar sebanyak 98\% responden sering memberikan kasih sayang kepada anak, 85\% responden menyatakan kadangkadang memberikan hadiah kepada anak, 83\% responden menyatakan kadangkadang mengabulkan setiap keinginan anak. Walaupun orang tua mempunyai kesibukan diluar rumah namun tidak boleh memanjakan anak sebagai imbalan. Sebanyak 81\% responden mengaku belum 
bersikap jujur kepada anak.

Disiplin sangat penting bagi perkembangan kepribadian anak sehingga menimbulkan pribadi anak yang mandiri. Sebanyak $76 \%$ responden menyatakan kadang-kadang memberikan disiplin kepada anak. Tentang pendidikan anak, sebanyak $89 \%$ responden setuju bahwa sekolah terkenal dapat membuat anak menjadi pintar, padahal faktor yang terpenting ialah dari anak dan orang tuanya sendiri. Pada umumnya (81\%) responden tidak membiarkan anak menyelesaikan masalahnya sendiri.

Tentang tugas anak di rumah, sebanyak 94\% responden menyatakan anak tidak dibiasakan membantu orang tua. Dalam hal cara anak bersosialisasi, pada umumnya sudah cukup baik. Hasil penelitian menunjukkan bahwa $86 \%$ orang tua sering mengajarkannya kepada anak. Dalam hal kepribadian anak, sebanyak 82\% responden kadang- kadang memiliki anak yang bertanggung jawab. Pada umumnya orang tua (82\%) mempunyai anak yang ramah, 78\% mempunyai anak yang kreatif, 83\% mempunyai anak yang pemalas. Ini sesuai dengan hasil penelitian tentang orang tua tidak membiasakan anak untuk membantu orang tua. Anak yang emosional $68 \%$ dan anak yang tidak pemurung 93\%. Sebanyak 83\% responden menyatakannya anak yang berkepribadian penakut, dan 83\% anak yang pinter berbicara. Pernyataan responden tentang memiliki anak yang kadang-kadang pemalu sebanyak 90\%, anak yang sulit bergaul dengan orang lain sebanyak 92\%, dan anak yang percaya diri sebanyak $89 \%$.

\section{SIMPULAN}

Gambaran pemahaman sikap orang tua terhadap anak yaitu: 95\% orang tua setuju dalam menanamkan budi pekerti kepada anak; $76 \%$ orang tua mengaku kadangkadang masih mendisiplin anak mereka; $81 \%$ orang tua belum berani jujur kepada anak-anak mereka; 94\% orang tua setuju memberikan tugas-tugas di rumah untuk dikerjakan oleh anak-anak mereka.
Gambaran pengaruh sikap orang tua terhadap kepribadian anak yaitu: $81 \%$ responden mengambil sikap tidak pernah membiarkan anak-anak mereka dalam menyelesaikan masalahnya sendiri, serta menilai banyak hal-hal positif yang ditunjukkan oleh anak-anak mereka, seperti kepribadian bertanggung jawab, ramah, memiliki rasa percaya diri yang tinggi dan kreatif serta mudah bergaul. Sebanyak 86\% responden mengajarkan anak bersosialisasi dengan lingkungan masyarakat.

Gambaran berbagai kepribadian anak berdasarkan sikap orang tua yaitu: orang tua yang bersikap mendidik anak dengan penuh kasih sayang menghasilkan kepribadian anak yang lebih bertanggung jawab sebanyak 82\%, anak yang ramah $88 \%$, anak yang kreatif $78 \%$.

Sebanyak $82 \%$ orang tua terlalu memanjakan anak sehingga menghasilkan kepribadian anak yang pemalas. Sebanyak 93\% orang tua tidak pernah memberikan hukuman fisik kepada anak sehingga menghasilkan kepribadian anak yang tidak pemurung, 83\% menjadi anak yang kadang-kadang penakut. Sebanyak 83\% orang tua mengajarkan anak bersosialisasi dengan lingkungan sekitar sehingga menghasilkan kepribadian anak yang mempunyai ketrampilan berbahasa yang baik.

\section{DAFTAR PUSTAKA}

1. Singgih GD. Psikologi Untuk Membimbing Jakarta: PT. BPK Gunung Mulia, 2007.

2. Harian Kompas. Sikap orang tua terhadap anak di Amerika serikat dan Cina. Jakarta, 2012. Available from: http://hariankompas.co.id.

3. Minahasa. Mapalus ciri khas budaya Minahasa, 2012. Available from: http://budayaminahasa.id.

4. Antara News. Tawuran Pelajar Meningkat, 2012. Available from: http://antaranews.com.

5. Walgito B. Pengantar Psikologi Umum. Yogyakarta: Penerbit Andi, 2004.

6. Davidoff LL. Introduction to Psychology, Walgito B, penyunting. Tokyo: McGraw-Hill International Student Edition, 1981. 
7. Bahan kuliah Psikologi Kedokteran pada Fakultas Kedokteran Unsrat.

8. Warta St. Andreas. Orang Tua Otoriter. 2012. Available from: http://ciluarkeuskupanbogor.or. id

9. Shvoong. Definisi Kepribadian. 2011. Available from: http://kumpulanistilah.blogspot.

10. Sjarkawi. Pembentukan Kepribadian Anak. Jakarta: PT. Bumi Aksara, 2008.

11. Wibowo H. Psikologi untuk pengembangan diri. Bandung: Widya Padjadjaran, 2010.

12. Wordpress.com 2012. Bagaimana kepribadian anak setelah orang tua bercerai. Available from: http://arradew.wordpress.com.

13. Life style. Dampak Kekerasan Terhadap Anak. 2012. Available from: http://id.shvoong.com.

14. Saifuddin A. Metode Penelitian. Yogyakarta: Pustaka Pelajar, 2013.

15. Sumadi S. Metodologi Penelitian. Jakarta: PT Raja Grafindo Persada, 2003.

16. Sugiyono. Metode Penelitian Administrasi. Bandung: Penerbit Alfabeta, 1994.

17. Subagyo J. Metode Penelitian. Jakarta: Rineka Cipta, 2006. 